\title{
CLIL-ing Your Coursebook
}

\section{CLIL-ar su texto}

David A. Hill

Freelance Teacher Trainer

\begin{abstract}
This article suggests that CLIL is an important new approach to language teaching, at last grounding lesson content in something educational, rather than the endless trivia of many coursebooks for general English. However, the dearth of suitable materials available is noted, and the suggestion is that teachers create their own CLIL materials starting from suitable parts of their own current coursebook, rather than wait a few years for the ELT publishing market to respond to the need for new materials. It then exemplifies this approach with reference to a page from a course for 11-12 year olds written for the Bulgarian market, showing how materials can be built out from what is within the book.
\end{abstract}

Key Words: CLIL; material design; adaptation; teenagers; coursebook.

\section{Resumen}

El artículo sugiere que CLIL es un nuevo enfoque para la enseñanza de idiomas, y con el fin de fundar contenido de clases en algo educacional, en cambio de las trivialidades que contiene muchos libros de texto de ingles general. Sin embargo, la falta de materiales apropiadas disponibles esta observado, y la sugerencia es que los mismos docentes creen sus propios materiales para CLIL, empezando con las partes apropiadas de libros de texto existentes sin tener que esperar años para que los editoriales produzcan nuevas materiales. Después hay unos ejemplos de este enfoque, con referencia de una página de un curso diseñada para estudiantes de 11-12 años, escrito para el mercado búlgaro, mostrando cómo se puede diseñar materiales basada en contenidos existentes.

Palabras Claves: CLIL; materiales; adaptación; adolescentes; texto.

\section{INTRODUCTION}

In 1993 and 1994 at the TESOL-Italy Conference in Rome I gave two related plenary talks entitled Walls and Bridges: Content-based Approaches to ELT and Let the Learners be the Content. These were born of a number of strands in my own and others' thinking about ELT at that time:

- worries that the majority of coursebooks only dealt in random trivia and grammar; my own background in project-based UK primary practice, which at that time I was using with Italian primary teachers, as a foreign language had recently been introduced at that level;

- information on the practice of and research into the bilingual immersion schemes in Canada, where students were taught other subjects in either English or French, depending on their mother tongue;

Hill, D. A. (2009). CLIL-ing your coursebook. Latin American Journal of Content \& Language Integrated Learning, 2(2), 31-36. doi:10.5294/lacli1.2009.2.2.13 
- and finally the idea that almost no students were interested in English per se - state school students did it because it was a subject on the timetable, private language school students did it because they could get promotion in their (for example) bank if they could speak another language, young children did it because their parents believed it was important and sent them to a private language school, and a few did it for social reasons.

I felt, overwhelmingly, that mainstream ELT was going in the wrong direction: we should not be teaching people English, we should be helping people to develop through English; a real content seemed the way forward.

In a further examination of the area in a Plenary talk called What Should Language Teaching Be About? at the IATEFL Hungary Conference in Veszprém in 2002, I did an analysis of the "big four" UK best-selling ELT coursebooks looking for "content". I defined content as either extrinsic content: something educationally worthwhile and interesting, or intrinsic content: activities where the students and their own real lives formed the content. As you might imagine, the amount of time devoted to either of these areas was minimal.

I have felt relieved that the EU has, under the name of CLIL (a rose by any other name smells just as sweet!!), decided to promulgate the idea that people at school ought to be learning something worthwhile through English.

Despite publishers developing materials as fast as they can, both free-standing subjectbased materials like the Macmillan Vocabulary Practice Series, or putting CLIL pages into every new coursebook, it is going to be a long time before the average coursebook-using classroom teacher around Europe actually works in this way. So over the past few years in some of my teacher training work, I have been working with the idea of CLIL-ing the coursebook. This is another rose by another name, because it is really just a more specific way of looking at how teachers can adapt their coursebooks to make them more relevant to their own particular class, which is surely a standard part of any worthwhile teacher training program.

\section{CLIL-ING THE COURSEBOOK: AN EXAMPLE}

Since 2006, I have been working with the major Bulgarian educational publisher, Prosveta, and I am using a page from one of their coursebooks to exemplify the process of CLIL-ing the coursebook. What follows is one of a series of lesson plans I have developed for teacher-training purposes, to use with Bulgarian teachers. It is based around page 103 of Hello! English (Sofia: Prosveta, 2007), a Bulgarian coursebook for $6^{\text {th }}$ grade, which means $11 / 12$ year-olds. Its aim is to use the main topic of the page (birds) and widen that, to include some genuine non-language (CLIL for biology) learning. It also uses an extract from the book $A$ Kestrel for a Knave and the film version of it, Kes. The lesson is student-centered, and starts from what the students know in order to build up general and language knowledge together. The procedure used is a term I have coined: "in-and-out work", the "in" being when the book is used, and the "out" when the book is not used.

\section{The lesson plan}

A. Out work

1. Naming birds

Hill, D. A. (2009). CLIL-ing your coursebook. Latin American Journal of Content \& Language Integrated Learning, 2(2), 31-36. doi:10.5294/lacli1.2009.2.2.13 
a. Show a picture of a bird to the class. Ask: What's this? Just expect the generic answer It's a bird. You could then ask: Does anyone know what sort of bird it is? And tell them if no one knows.

b. Say: Make a list of the names of all the birds you know. Give them some clues if necessary-for example: Think about pet birds, zoo birds, the birds in your garden.

c. Say: Get into groups of four to share what you wrote. Say: Somebody be the secretary and write down the group list.

d. Call back the lists from the secretaries, and make a class master list on the board.

e. If there are any missing types which you consider important and interesting, you might try to elicit them with questions such as: What do we call those black and white birds which can't fly, but swim and catch fish in the Antarctic? (Penguin); Do you know the name of those big birds which live in our mountains and catch small animals to eat? (Eagle); What's the name of those white birds which you see at the seaside? (Gull); and so on. If they are unable to give them, then write up the names and teach them. (You must have: hawk, falcon, eagle, owl, crow, parrot, hen, as these occur in the book; you might add the following as important: other domestic and local wild birds: duck, goose, turkey, canary, budgerigar, swan, heron, blackbird, swallow, lark, tit, finch, robin, pigeon, dove, woodpecker, cuckoo, pheasant, gull, penguin, pelican.)

f. Say: Work in your groups of four and make a list in columns of which birds are Bulgarian wild birds/farm birds/zoo or pet cage birds. Tell them: Some birds can appear in two columns.

Here is a completed table, using the types of birds given above:

\begin{tabular}{|c|c|c|c|}
\hline \multicolumn{2}{|c|}{ Bulgarian wild birds } & Farm birds & Zoo or pet cage birds \\
\hline $\begin{array}{l}\text { Hawk } \\
\text { Falcon } \\
\text { Eagle } \\
\text { Owl } \\
\text { Crow } \\
\text { Duck } \\
\text { Goose } \\
\text { Robin } \\
\text { Dove } \\
\text { Cuckoo } \\
\text { Gull }\end{array}$ & $\begin{array}{l}\text { Swan } \\
\text { Heron } \\
\text { Blackbird } \\
\text { Swallow } \\
\text { Lark } \\
\text { Tit } \\
\text { Finch } \\
\text { Pigeon } \\
\text { Woodpecker } \\
\text { Pheasant } \\
\text { Pelican }\end{array}$ & $\begin{array}{l}\text { Duck } \\
\text { Goose } \\
\text { Hen } \\
\text { Turkey }\end{array}$ & $\begin{array}{l}\text { Parrot } \\
\text { Canary } \\
\text { Budgerigar } \\
\text { Penguin } \\
\text { Pigeon }\end{array}$ \\
\hline
\end{tabular}

g. Give out the pictures of the birds - one to each student if possible (or one to each pair if your resources are more limited).

h. Ask: Can you identify your bird? Say: Hold up your picture to show the class and say "I've got a ..." or "This is a ...".

Hill, D. A. (2009). CLIL-ing your coursebook. Latin American Journal of Content \& Language Integrated Learning, 2(2), 31-36. doi:10.5294/lacli1.2009.2.2.13 
2. Describing birds

a. Give out the outline drawing ${ }^{1 *}$ of the bird and say: Label the different parts of the bird using the words I am writing on the board (Write: head, eye, beak, neck, back, wing, breast, tail, leg, claws.)

b. Check that they do this correctly, by calling back answers from the class (What's this? It's a wing.) and labeling a master drawing on the board. I typically find that beak, breast and claws are the new words and the ones which need a little repetition practice.

c. Say: Describe your color picture of a bird to your partners, using the parts of the body, colors and other words (for example; My bird is a woodpecker. It's black and white with red on its neck. It has a sharp beak.). They can do this first with their partners and then for the whole class.

d. Say: The birds have different shapes to their beaks, claws and wings depending on how they live. Look at this parrot - it has a big strong beak so it can break open fruit and nuts. Look at your bird and decide what it can do.

e. Say: Tell your partner what your bird can do (for example: My woodpecker can break wood with its sharp beak; My heron can walk in water with its long legs). You can then have the students ask the class things like: What do you think my robin can do? And have the class answer: It can catch insects with its small thin beak.

B. In work

1. Hello! English for the $6^{\text {th }}$ Grade, page 103.

a. Say: Open your books to page 103. Look at the Reading section.

b. Read the text. What pets has Misato got? Tick the pictures. Note: In the book there is the text below surrounded by high-quality, labeled, color photos of a hawk, a falcon, a crow, an owl, a hen and a parrot, with a box next to each name for the students to tick. The text is as follows:

The Girl Who Trains Falcons

Misato is a fifth-grade elementary school student in Takeo, Japan. She has got two unusual pets: a hawk and a falcon. Misato thinks of the two birds as members of her family. The hawk's name is Momotaro and the falcon's called Shiro. Eagles, falcons, hawks and owls are endangered in Japan.

Every day Misato feeds her birds and trains them to scare away the crows that cause problems for local farmers. Sometimes when Misato has to stay late after school for kendo club practice, her grandfather looks after the birds.

Misato wants to continue learning more about animals and nature. Her dream is to become a vet when she grows up. She hopes she can create a world where people and animals can live together in harmony. (p.103)

c. When they have completed the activity individually, ask them to check with a partner.

d. Call back the answers from the whole class.

e. Ask the students who have the pictures of the sparrowhawk (hawk) and kestrel (falcon) to show their pictures to the class. Discuss them in detail with the class.

\footnotetext{
${ }^{1}$ This is a simple outline drawing of a "generic" perching bird rather like a blackbird which I drew, with the various parts of the body clearly evident so that they are easy to label. Head is already labeled as an example.
}

Hill, D. A. (2009). CLIL-ing your coursebook. Latin American Journal of Content \& Language Integrated Learning, 2(2), 31-36. doi:10.5294/laclil.2009.2.2.13 
f. Discuss some of the bird-related elements of the text with them: what is meant by scaring crows, endangered animals, training a falcon, and so on.

g. Say: Do activity 14 by yourselves, then check with a partner. Note: Exercise 14 is a 5-part half-sentence matching activity based on the text above.

h. Call back the answers as complete sentences from the whole class.

C. Out work

1. The Book and the Film

a. Ask: What birds did Misato keep? (A hawk and a falcon.) What does she use them for? (Scaring crows.)

b. Ask: Do you know any other things people can use falcons for? (Keeping birds off airports to prevent bird strikes with planes. Hunting for food for the owner.)

c. Ask: Do you know how people train falcons? Elicit suggestions.

d. Show them the extract from the film Kes and/or read the same section from the book $A$ Kestrel for a Knave.

e. Say: Describe what Billy was doing. Describe the bird. What was the teacher's reaction to what he saw? What did you think about the bird and what was happening?

\section{CONCLUSIONS}

As can be seen, the lesson plan takes a simple text, which otherwise would remain "random trivia" for the students, and turns it into something which gives them some basic knowledge about the biology of birds, the names of a set of common birds and an idea about what training a falcon might involve. In other words they are doing something with their English - an opportunity to actually learn something through English is being offered.

It is plain that putting together something like this is quite time-consuming. It involves this process on the part of the teacher:

1. Recognizing the CLIL potential of a particular section of their coursebook

2. Deciding how best to work out of the coursebook so that it is appropriate for the age and interests of the students

3. Finding and writing suitable additional materials (pictures, texts, activities)

4. Planning the lesson so that it is both student-centered and coherent

However, this way of working approaches what many would consider "best practice" in terms of classroom teaching. I believe that the practicing classroom teacher can produce such a lesson once every three to four weeks, which means that they could produce around ten of them in the typical European 30-35-week school year. The time-saving part is that once written, the lesson plan can be used again with other groups to which are taught using the same book this year, and with new classes at the same level in the following years. Thus, given that the fact that teachers are often constrained by education authorities to use the same coursebook for a minimum threeyear period or do so anyway, they might have CLIL lessons available for many/most sections of the book after a couple of years.

Hill, D. A. (2009). CLIL-ing your coursebook. Latin American Journal of Content \& Language Integrated Learning, 2(2), 31-36. doi:10.5294/laclil.2009.2.2.13 


\section{REFERENCES}

Hill, D.A. \& Pulverness, A. (Eds). (2009). The Best of Both Worlds? International Perspectives on CLIL. Papers from the NILE Conference held at The University of East Anglia, Norwich $5^{\text {th }}-7^{\text {th }}$ September, 2008. Norwich: NILE.

Hines, B. (1968). A Kestrel for a Knave. Harmondsworth: Penguin.

Loach, K. (Dir.) (1970). Kes. MGM.

Petkova, D. \& Koleva, E. (2007). Hello! English for the $6^{\text {th }}$ grade. Sofia: Prosveta.

\section{BIODATA}

David A. Hill is a freelance teacher trainer and materials writer working out of Budapest. He is a specialist in teaching young learners and teenagers, literature, British studies and materials development. He has trained teachers for the Norwich Institute for Language Education (NILE) every summer since 1998, and regularly travels to over ten countries each year to work on a range of projects with students, teachers, publishers and education authorities. He is currently coordinator of the IATEFL LMCS SIG. 